\title{
To Assess the Level of IgG among Smokers: A Clinical Comparative Study
}

BACKGROUND: Immunoglobulins shows a significant increase especially among smokers and gutka chewers.

AIM: The present study aimed at estimation of immunoglobulins in smokers.

MATERIALS \& METHODS: The present study was conducted on 80 subjects and divided into two groups A and B where serum level was estimated by automated Nephelometry method.

RESULTS: The mean level of IgG was 11.34 in group A and 5.89 in group B which was statsically significant $(\mathrm{P}<0.05)$.

CONCLUSION: The raised level of IgG in smokers as compared to control increase the possibility of detecting the lesions at early stages and act as alarming approach for many of the dentists.

KEYWORDS: Immunoglobulins, Leukoplakia, Smokers, Serum level, Nephelometry

\section{INTRODUCTION}

Tobacco usage is the leading preventable public health problems and despite of many efforts still people are into this habit. Though harmful effect of smoking on human body is well established but sadly many of the people are using tobacco in smokeless form or smoking form. Smokeless form comprised of zarda, chaini khaini, pan masala, pan pasand and mishri etc. Smoking form comprised of cigarette, bidi, hookah, hookli etc. ${ }^{1}$

The most common side effect of tobacco on oral cavity is the formation of pre-cancerous lesions and conditions. Pre-cancerous lesions are defined as morphologically altered tissue in which cancer is most likely to develop than its apparently normal counterpart. Pre-cancerous conditions are defined as generalized state of body associated with significantly increased risk of cancer. ${ }^{2}$ Leukoplakia, erythroplakia and palatal changes associated with reverse smoking are examples of pre-cancerous lesions and systematic lupus erythematosus, oral syphilis, oral lichen planus, sideropenic dysphagia, xeroderma pigmentosum, epidermolysis bullosa etc. are examples of Precancerous conditions. ${ }^{3,4}$

Not only these, even tobacco's effects can be seen on general body as respiratory system, and cardiovascular systems are commonly affected with smoking. Lung cancer and nasopharyngeal cancer are also result of tobacco usage. Immunoglobulins are raised in smokers and gutka chewers. Among five classes, IgA and IgG show significant increase in count. ${ }^{5}$ The present study was conducted in order to estimate the immunoglobulins in smokers.

\section{MATERIALS \& METHODS}

The present study was conducted in the department of Oral pathology and microbiology among 80 subjects who were registered at OPD of dental college. They all were informed regarding the objective of the study and written consent was obtained. Ethical clearance was obtained from institutional ethical committee prior to the study. Subjects with history of smoking were included and patients below age of 18 years and with any systemic illness were excluded. Subjects were divided into 2 groups. Group A (smokers) and group B(non- smokers). For serum immunoglobulins estimation about $2.5 \mathrm{ml}$ blood was collected from antecubital vein in all subjects. Separated serum was collected in separate container and serum level of IgG and IgA was estimated by automated Nephelometry method. A statistical analysis was performed by independent $t$ test and significant level of $p$ value was set at 0.05 .

\section{RESULTS}

In the present study demographic data was seen through table 1 and it was seen that studied population consist of 50 male ad 30 females with majority of the age group is 31-40 years. In table 2 , its seen that IgG level is more in smokers as compared to non-smokers which is highly 
significant.

\begin{tabular}{|c|c|}
\hline Gender & Number \\
\hline Male & 50 \\
\hline Female & 30 \\
\hline \multicolumn{2}{|c|}{ Age group } \\
\hline 20-30 years & 13 \\
\hline 31-40 years & 33 \\
\hline $41-50$ years & 21 \\
\hline 51 and more & 13 \\
\hline
\end{tabular}

Table 1. Distribution of subjects among studied population according to age and gender

\begin{tabular}{|c|c|c|c|}
\hline Group & $\begin{array}{c}\text { IgG level } \\
\text { Mean } \pm \text { SD }\end{array}$ & t value & $\begin{array}{c}\text { P } \\
\text { value }\end{array}$ \\
\hline Group A & $11.34 \pm 2.47$ & 1.095 & o.001* $^{*}$ \\
\hline Group B & $5.89 \pm 0.589$ & & \\
\hline
\end{tabular}

Table 2. Estimation of IgG level in groups (* signifies significant observations)

\section{DISCUSSION}

The habit of tobacco smoking is largely associated with appearance of white lesions in oral cavity. The immunoglobulins are greatly affected in patients with history of smoking or with mucosal lesions. It affects a wide range of immunological functions in human and experimental animals including both humoral and cell mediated immune responses. ${ }^{6}$

Studies are showing that tobacco use in any form affects immunoglobulin levels thus direct role in altering immune function of body. It has been shown in study that there is considerable immunosupression in smokers due to chronic exposure to nicotine by impairing antigen mediated signaling in T- cells. Smokers exhibit higher IgA and IgG level than control nonsmokers. In present study we assessed the level of IgG in smokers and non-smokers and it was seen that among smokers level of IgG was higher at significant level which is in agreement with Chaturvedi et al. ${ }^{7}$
It has been shown that in smokers there is irritation of respiratory and gastrointestinal mucosa by cigarette smoke. Since IgA is associated with seromucous membranes, it protects these membranes against soluble antigens by inhibiting their adherence to surface of mucosal cells. Hence the presence of tobacco smoke on these membranes results in enhanced production of this immunoglobulin. It may be suggested that continuous exposure to components of cigarette has stimulatory effects on immunoglobulin production, thus the increased levels of immunoglobulins. The raised levels of $\operatorname{IgG}$ in smokers might be one of the mechanisms to neutralize components of cigarette tobacco via complement activation. ${ }^{8,9}$

\section{CONCLUSION}

The raised level of IgG among smokers as compared to control increases the possibility of detecting the lesions at early stages. Thus the subjects with habit of smoking should be routinely assessed for IgG level. Dentists should be aware about this preventive approach along with other interventional strategies among smokers for quitting of habit.

\section{REFERENCES}

1. Bokor-Bratic M, Vuckovic N. Cigarette smoking as a risk factor associated with oral leukoplakia. Arch Oncol 2002; 10:67-70.

2. Patidar KA, Parwani RN, Wanjari SP. Correlation of salivary and serum IgG, IgA levels with total protein in oral submucous fibrosis. J Oral Sci 2011; 53:97-102

3. Moustafa SM, El-Elemi AH. Evaluation of probable specific immunotoxic effects of cigarette smoking in smokers. Egypt J Forensic Sci 2013; 3:48-52.

4. Cox SC, Walker DM. Oral submucous fibrosis. A review. Aust Dent J1996; 41:294-9.

5. Pinakapani R, Shambulingappa P, Shashikanth MC. Salivary Coagulopathy and immunoglobulins in oral submucous fibrosis. J Indian Acad Oral Med Radiol 2009; 2:62-66.

6. Pindborg J, Sirsat SM. Oral submucous fibrosis. Oral Surg Oral Med Oral Patholig66;22:764-79.

7. Chaturvedi VN, Marathe NG. Serum globulins and immunoglobulins in oral submucous fibrosis. Indian Pract 1988; 41:399-403.

8. Ranganathan K, Devi MU, Joshua E, 
Kirankumar K, Saraswathi TR. Oral submucous fibrosis: A case-control study in Chennai, South India. J Oral Pathol Med 2004;33:274-7.
9. Pathak AG. Serum proteins and immunoglobulins in oral submucous fibrosis. Indian J Otolaryngol 1978;30:1-4.

Cite this article as:

Khan K, Jain M. To Assess the Level of IgG among Smokers: A Clinical Comparative Study. Int

Source of support: Nil, Conflict of interest: None declared

Healthc Res J. 2019;2(12):313-315. doi: 10.26440/IHRJ/0212.03.521061

\section{AUTHOR AFFILIATIONS:}

1. MDS (Public Health Dentistry), Private Practitioner, Jasola, New Delhi, India

2. Senior Lecturer, Department of Oral Medicine and Radiology, JN Kapoor DAV(C) Dental College, Yamuna Nagar, India

${ }^{*}$ Corresponding Author:

Dr. Mayank Jain

Senior Lecturer

Department of Oral Medicine and Radiology

JN Kapoor DAV(C) Dental College

Yamuna Nagar, India
For article enquiry/author contact details, e-mail at: editor.ihrj@gmail.com,editor@ihrjournal.com 